\title{
PENGARUH DIMENSI DARI SUPPLY CHAIN MANAGEMENT TERHADAP KINERJA OPERASIONAL TOKO KOMPUTER DI KOTA AMBON
}

\author{
Zainuddin Latuconsina dan Nathalia Dessy Sariwating \\ Fakultas Ekonomi dan Bisnis Universitas Pattimura \\ JL. Ir. M. Putuhena Kampus Poka-Ambon, 97233, Indonesia
}

\begin{abstract}
The purpose of this study was to analyze the effect of information sharing, long-term relationships, collaboration, process integration, and relationship quality on operational performance in Ambon restaurants. The population in this study is a restaurant in the city of Ambon. The sampling technique used was purposive sampling, with a total of 25 respondents. Data were collected using a questionnaire as the main instrument, and the questionnaire used a Likert scale to measure respondents' answers. Partial Least Square is used to identify the effect of supply chain management dimensions on operational performance. The results showed that information sharing affected operational performance (3,167> 2,045), long-term relationships affected operational performance (2,181> 2,045), collaboration affected operational performance (6,720>2,045), process integration on supply operational performance was not accepted (3,167 > 2,045), while the quality of the relationship does not affect operational performance $(0.654<2.045)$.
\end{abstract}

Keywords: Information Sharing, Long-Term Relationships, Cooperation, Process Integration, Supply Chain Performance.

JEL Classisfication : D83, A13, P19, F15, F19.

\section{PENDAHULUAN}

Indonesia merupakan negara yang memiliki pertumbuhan ekonomi yang stabil, bahkan dalam lapoman Bank Dunia yang berjudul "Global Development Horizons 2011 Multipolanity: The New Global Economy", disebutkan bahwa Indonesia bersama dengan Brasil, Cina, India, Korea Selatan dan Rusia adalah penopang pertumbuhan ekonomi dunia hingga 2025 mendatang. Bank Dunia menilai lebih dari $50 \%$ pertumbuhan ekonomi dunia akan disumbangkan oleh enam negara ini. Pertumbuhan ekonomi Cina dan Korea Selatan ditopang oleh arus ekspor yang tinggi, sementara untuk Indonesia dan Brasil pertumbuhan ekonomi dipicu oleh konsumsi dalam negeri yang tinggi.

Meningkatnya pertumbuhan bisnis berimplikasi pada naiknya permintaan dari pasar terhadap produk yang diinginkan.Dengan meningkatnya permintaan pasar terhadap produk atau barang yang dibutuhkan maka sektor perindustrian dalam hal ini yang memproduksi barang dituntut untuk bisa berinovasi dalam strategi baik dalam perencanaan ataupun memproduksi barang.Tuntutan dari pasar tersebut adalah sebuah tantangan bagi perindustrian yang mau ataupun tidak mau harus mereka hadapi sebagai sebuah jalan bagi mereka untuk tetap bertahan ataupun tergantikan.

(Ariani, Dwiyanto, 2013) menjelaskan bahwa pentingnya peran semua pihak mulai dari supplier, manufacturer, distributor, retailer, dan customer dalam menciptakan produk yang murah, berkualitas, dan cepatInilah yang kemudian melahirkan konsep baru yaitu Supphy Chaim Management. Suppby Chain Manogement adalah perluasan dan pengembangan konsep dan arti dari manajemen logistik, yang berperan dalam mengatur arus barang antar perusahaan dan semakin berkembang menyangkut kepada hal-hal yang dipertukan oleh pelanggan. Suppy Chain Managemen(manajemen rantai pasokan) adalah integrasi aktivitas pengadaan bahan dan pelayanan, pengubahan menjadi barang setengah jadi dan produk akhir, serta pengiriman ke pelanggan (Ariani et al., 2013).

Suppy Chain Management merupakan suatu pendekatan yang digunakan untuk mencapai pengintegrasian berbagai organisasi yang lebih efisien dari supplier, mamufaktur, distributor, retailer, dan customer. Artinya barang diproduksi dalam jumlah yang tepat, pada saat yang tepat dan pada tempat yang tepat dengan tujuan mencapai cost dari system secara keseluruhan yang 
minimum dan juga mencapai senvice lexel yang diinginkan (Fitrianto \& Sudaryanto, 2010)

Penelitian tentang Supply Chain Management (SCM) dilakukan oleh (Suharto \& Devie, 2013) yang mengembangkan lima dimensi praktek SCM (Strategic Supplier Partnership, Customer Relationship, Information Sharing, Level of information quality dan Postponement) dan menguii hubungan antara praktek SCM terhadap keunggulan kompetitif dan kinerja perusahaan. Hasil penelitian menunjukkan bahwa praktek SCM yang semakin baik berpengaruh positif terhadap peningkatan keunggulan kompetitif dan meningkatkan kinerja perusahaan.Selain itu keunggulan kompetitif berpenganuh langsung terhadap kinerja Operasional.

(J. Rachbini, 2019) menjelaskan bahwa pembagian informasi tidak berpengaruh terhadap performance, tetapi Relationship berpenganuh positif terhadap performano. (Huda et al, 2018) aliran informasi tidak berpengaruh terhadap kinerja. (J. Rachbini, 2019), Supply Chain Management berpengaruh positif terhadap kinerja perusahaan. Dengan semakin pentingnya penerapan SCM pada perusahaan, maka ingin digali lebih dalam mengenai Suppy Chain Mangeement yang mempengaruhi peningkatan kinerja operasional.

Saat ini merupakan era digitalisasi dan tidak dapat dipungkiri bahwa fungsi komputer di bidang bisnis maupun akademis memiliki peranan yang sangat penting. Dalam bidang bisnis, komputer berperan untuk meningkatkan kinerja operasional perushaan. Sedangkan akademis, komputer berperan dalam membantu menyelesaikan tugas-tugas yang diberikan oleh guru atau dosen, dan lain-lain. Dalam perkembangannya komputer tidak hanya terdiri atas komputer desktop atau yang lebih dikenal dengan sebutan PC (Personal Computer) dengan menggunakan daya listrik 220 volt, akan tetapi komputer sekarang ada yang lebih praktis dan bisa mobile dengan menggunakan rechargeable notebook atau lebih dikenal dengan sebutan laptop. Adanya laptop memungkinkan para pengguna untuk bisa menggunakan komputer dimanapun.

Laptop pertama kali ditemukan oleh Alan Kay pada saat itu bertujuan untuk membuat komputer agar dapat dibawa tanpa memerlukan kabel dan berukuran kecil. Sampai saat ini telah banyak perkembangan dan inovasi yang menghasilkan sebuah laptop yang mempunyai banyak fungsi. Bukan hanya mempunyai banyak fungsi tetapi juga mempunyai berbagai jenis ukuran dari 10 inchi hingga 17 inchi yang memudahkan untuk dibawa berpergian dan mengerjakan pekerjaan di lapangan tanpa memerlukan arus listrik. Sekarang banyak perusahaan yang memproduksi secara masal laptop dengan berbagai fitur dan kecanggihan yang ditawarkan kepada pelanggan. Perusahaan itu diantarannya adalah Acer, HP (Hewlett Packard), ASUS, Toshiba, Dell, Lenovo. Perusahaan tersebut berkompetisi untuk dapat meningkatkan pangsa pasar dengan berorientasi pada pelanggan. Pelanggan cenderung memilih laptop yang sesuai dengan kebutuhan mereka. Biasanya konsumen yang suka chatting atau word processing cenderung menyukai laptop dengan ukuran layar 10 inci dengan processor sekelas Intel Atom, karena mempertimbangkan faktor umur baterai, berat laptop, ukuran layar, serta beberapa fitur internal konektifitas seperti WiF; Bhetooth, NetwonkCand, Modem. Sedangkan pelanggan gamers dan graphic design akan memilih laptop yang berukuran 12 inci - 17 inci dengan mempertimbangkan processor dan memori dengan spesifikasi tinggi agar bisa mengimbangi perkembangan piranti, lunak dan developing tooks. Peneliti disini akan meneliti salah satu produsen komputer yaitu Asus. Asus menjadi salah satu produsen komputer dengan penjualan notebook tertinggi di Indonesia.

\section{LANDASANTEORITIS}

\section{Teori Supply Chain Management}

Suppy Chain Management sebagai istilah bagi pengelolaan rantai pemasok dan pembeli, yang mencakup semua tahap pemrosesan dari pembelian bahan baku sampai pendistribusian barang jadi kepada konsumen akhir. Supply Chaim Management (manajemen rantai pasokan) adalah integrasi aktivitas pengadaan bahan dan pelayanan, pengubahan menjadi barang setengah jadi dan produk akhir, serta penginiman ke pelanggan. Tujuannya adalah untuk membangun sebuah rantai pemasok yang memusatkan perhatian untuk memaksimalkan nilai bagi pelanggan. Kunci bagi manajemen rantai pasokan yang efektif adalah menjadikan para pemasok sebagai "mittra" dalam strategi perussahaan untuk memenui pasar yang selalu berubah (Barata, 2016) Suppy Chaim Management merupakan kegiatan pengolahan bahan mentah menjadi barang dalam proses atau barang setengah jadi dan barang jadi kemudian mengirimkan produk tersebut ke konsumen melalui sistem distribusi. Kegiatan ini mencakup fungsi pembelian yang berhubungan antara pemasok dan distributor (Huda et al, 2018). Manajemen rantai pasokan adalah perencanaan strategis dari peranan masing-masing organisasi yang terlibat disepanjang aktivitas rantai pasokan dengan tujuan untuk mengintegrasikan manajemen rantai pasokan dan permintaan. Menciptakan sistem manajemen rantai 
pasokan yang efektif akan bermanfaat pada perusahaan diantara manfaat tersebut yaitu, persediaan dan biaya yang lebih efisien, meningkatnya produktivitas, pemrosesan dan pengiriman yang lebih cepat, laba yang lebih besar, dan kesetiaan pelanggan yang meningkat (Anggini, 2007) mendefinisikan manajemen rantai pasokan sebagai fokus ilmu yang mengintegrasikan dan mengelola pergerakan barang dan jasa serta informasi dalam rantai pasokan supaya responsif terhadap kebutuhan pelanggan sambil menurunkan total biaya.

\section{Pembagian Informasi}

Pembagian informasi adalah intensitas dan kapasitas perusahaan dalam interaksinya untuk saling berbagi informasi kepada partner berkaitan dengan strategi-strategi bisnis bersama. Information sharing juga memungkinkan anggota rantai pasok untuk mendapatkan, menjaga, dan menyampaikan informasi yang dibutuhkan untuk memastikan pengambilan keputusan menjadi efektif, dan merupakan factor yang mampu mempererat elemenelemen kolaborasi secara keselunuhan oleh karena itu kemacetan industri dapat dikurangi dengan adanya information sharing (Simatupang \& Sridharan dalam Yaqoub, 2012) dalam (Yun \& Kurniawan, 2019)

\section{Hubungan Jangka Panjang}

(Ariani et al, 2013) mendefinisikan hubungan jangka panjang sebagai persepsi mengenai saling ketergantungan pembeli terhadap pemasok baik dalam konteks produk atau hubungan yang diharapkan akan membawa manfaat bagi pembeli dalam jangka panjang. Hubungan antara supplier, customer, dan perusahaan, harus dikelola dengan baik dan selalu ditingkatkan agar terjalin hubungan yang berkelanjutan dan supplier ikut bertanggungiawab terhadap kualitas produk serta agar distribusi produk dari hulu ke hilir tepat pada waktunya sampai ke pengguna akhir. Maka peningkatan hubungan yang baik dalam jangka panjang serta saling adanya kepercayaan antara perusahaan, suppher dan customers angat diperlukan agar mencapai efisiensi dalam kinerja perusahaan (Talumewo et al., 2014) prinsip dari pengelolaan hubungan jangka panjang dengan tujuan akhir yang ingin dicapai yaitu profitabilitas perusahaan yang diperoleh secara terus menerus melahui hubungan yang saling menguntungkan sehingga diharapkan tercipta hubungan jangka panjang yang konsisten dan berkesinambungan.

\section{Kerjasama}

(Fitrianto\& Sudaryanto,2010) mengatakan, kerjamsama merupakan salah satu altemative yang terbaik dalam melakukan supply chaim monagement yang optimal. Alasannya karena diantara organisasi atau perusahaan yang berada pada jaringan supply chaim manggement, sudah pasti memerlukan sistem informasi yang akurat, dan lancer serta memertukan kepercayaan antara peserta pengadaan barang dan jasa. Semua itu tidak akan bisa tercapai tanpa adanya kerjasama yang baik. Adanya kerjasama dengan supplier yang dapat diandalkan diharapkan akan menghasilkan pengertian dan pemahaman yang baik akan kebutuhan dan keperluan masing-masing pihak (Huda et al., 2018).

(Hakim, 2018) menyatakan dengan adanya kerjasama dengan supplier yang baik akan kebutuhan yang dapat diandalkan serta diharapkan dapat menghasilkan pemahaman dan pengertian yang baik akan keperluan dari masing-masing pihak sehingga dapat meningkatkan profitabilitas dari perusahaan itu sendiri. Kualitas hubungan dapat diukur dengan menggunakan dimensidimensi pengukuran yang digunakan yaitu kepercayaan (trust) dan kejujuran (faimess) sebagai dimensi-dimensi pengukuran kualitas dari suatu hubungan kerjasama (Bujang, 2007).

\section{Teori Proses Integrasi}

Suatu integrasi harus dicapai oleh organisasi atau perusahaan yang terlibat di dalam suppy chaim management dan seluruh supplier pengadaan bahan. Tujuan dari supply chain management adalah mengintegrasikan selunuh proses operasional perusahaan mulai dari hulu (upstreams) dan ke hilir (downstreams) sampai pada pengguna akhir, melalui penyediaan produk, informasi, dan jasa guna dalam meningkatkan nilai tambah bagi konsumen dan stakeholder lainnya.

\section{Sinkronisasi Keputusan}

Sinkronisasi keputusan dapat didefinisikan sebagai sejauh mana anggota rantai mampu mengatur keputusan kritis pada perencanaan dan tingkat eksekusi untuk mengoptimalkan profitabilitas rantai pasokan (Simatupang \& Sridharan, 2006) dalam (Zainuddin Latuconsina,2015). Kegiatan ini meliputi penyusunan proses pengambilan keputusan bersama, termasuk penempatan hak keputusan secara mandiri dalam rangka sinkronisasi perencanaan rantai pasokan dan eksekusi yang berusaha untuk mencocokkan permintaan dengan pasokan. Cara untuk menilai sinkronisasi keputusan yang efektif 
didasarkan pada efek pada respon yang akurat terhadap pemenuhan tuntutan pelanggan (yaitu. manfaat logistik) dan profitabilitas rantai pasokan (yaitu manfaat komersial)

\section{Penyelarasan Intensif}

(Rani et al, 2017) keselarasan insentif atau imcentix aligmment adalah sering tidaknya anggota rantai pasok saling berbagi kerugian, resiko dan manfaat. Indikator keselarasan insentif ini meliput jaminan pengiriman untuk puncak permintaan, skema insentif jangka panjang untuk kualitas standar produk yang tinggi dan perjanjian dalam perubahan pemesanan.

Penyelarasan Intensif adalah sikap menghadapi permasalahan dalam memotivasi anggota yang berpartisipasi dalam menciptakan nilai yang menguntungkan seluruh anggota. Penyelarasan intensif juga meliputi aktivitas berbagi biaya, resiko, dan keuntungan antar anggota yang berpartisipasi dalam supply chaim bisnisnya (Simatupang \& Sridharan, 2008) Penyelarasan Intensif bertujuan untuk menyediakan mekanisme untuk menyetarakan kembali keuntungan dan beban bersama yang terjadi dalam proses perubahan pada supply chain (Simatupang \& Sridharan, 2004a) dalam (Zainuddin Latuconsina 2015).

\section{Kinerja Operasional}

Kinerja adalah gambaran mengenai tingkat pencapaian pelaksanaan tugas suatu organisasi dalam upaya mewujudkan sasaran, tujuan, misi\&visi organisasi tersebut. Adalah sebuah kinerja operasional organisasi dikonseptualisasikan sepanjang dimensi biaya, kualitas, fleksibilitas dan penginiman.

Menurut (Rani, 2017) merupakan hasil dari fungsifungsi pekerjaan atau kegiatan yang ada dalam perusahaan yang dipengaruhi faktor intem dan ekstem organisasi dalam mencapai tujuan yang telah di tetapkan selama periode waktu tertentu. Gambaran variabel kinerja operasional dalam penelitian ini mengambil dua aspek dari pendekatan balanned sonecand, yaitu perspektif proses bisnis internal dan prespektif pelanggan seperti ketersediaan barang, biaya persediaan, pembelian kembali, kualitas barang, tingkat omplaim, dan kepuasaan pelanggan.

Pengukuran kinerja rantai pasok suatu perusahaan berdasarkan perspektif strategi operasi meliputi pengukuran kinerja yang berdomain sumber daya, kemampuan operasional, serta proses operasional. Mengacu pada definisi tersebut, Simatupang \& Sridharan mengusulkan tiga dimensi pengukuran kinerja operasional dalam konteks rantai pasok berdasakan perspektif strategi operasi yakni fufflilment, imentory performance, dan responsiueness.

Imentory berfungsi untuk mengidentifikasi sejauh mana praktik kolaborasi perusahaan dalam jaringan rantai pasok mampu melakukan pengelolaan persediaan yang meliputi tingkat perputaran persediaan, pengurangan jumlah persediaan, dan pengurangan biaya persediaan. Selanjutnya responswieness berfungsi untuk mengidentifikasi sejauh mana praktik kolaborasi perusahaan dalam jaringan rantai pasok mampu merespon permintaan konsumen yang meliputi tingkat pengurangan waktu tunggu, fleksibilitas dalam mengakomodasi permintaan, dan kepekaan terhadap permintaan konsumen.

\section{Hubungan Variabel Antara Pembagian Informasi terhadap Kinerja Operasional}

Pembagian informasi adalah sejauh mana informasi penting dikomunikasikan terhadap mitra usaha perusahaan.Tingkat pembagian informasi berkaitan dengan tingkat kepentingan dan ketepatan informasi yang dikomunikasikan ke mitra bisnis dalam rantai pasokan.Pembagian informasi merupakan salah satu faktor penting dalam implementasi manajemen rantai pasokan. Pembagian informasi merupakan salah satu dari building blocks yang menunjukkan hubungan yang solid antar mitra bisnis yang tergabung dalam rantai pasokan.

Penelitian yang dilakukan oleh Anatan yang mengemukakan faktor anteseden yang harus diperhatikan dalam pengelolaan rantai psokan untuk menjamin kualitas informasi mencakup tiga hal utama yaitu : ketidakpastian lingkungan, fasilitator intra-organisasional dan hubungan inter-organisasional menyatakan bahwa information sharing dapat membantu perusahaan dalam memperbaiki efisiensi dan efektivitas rantai pasokan dan merupakan faktor yang paling penting untuk mencapai koordinasi yang efektif dalam rantai pasokan serta menjadi pengendali di sepanjang rantai pasokan. Information sharing menjamin tersedianya data tepat waktu sehingga data yang dimiliki dapat dibagikan disepanjang rantai pasokan, serta dapat merespon perubahan kebutuhan dan keinginan konsumen lebih cepat. Oleh karena itu, pemahaman faktor-faktor yang mempengaruhi information sharing dan kualitas informasi sangat di butuhkan untuk menunjang kualitas dan proses pembagian informasi, dan meningkatkan kinerja operasional yang baik.

Hipotesis 1 : Pembagian Informasi berpengaruh posititf terhadap Kinerja Operasional

Hubungan Variabel antara Hubungan Jangka Panjang terhadap Kinerja Operasional 
Menurut Zineldin dalam (Fitrianto \& Sudaryanto, 2010) kualitas sebuah hubungan merupakan fungsi dari beberapa elemen atau faktor-faktor tertentu di antaranya:kooperasi, kemampuan dan kinerja karyawan termasuk manajer, sumber daya fisik, kualitas, distribusi dan penentuan harga produk, pembagian informasi, pengalaman, harapan konsumen dan kepuasan.

Hubungan antara supplier, customer, dan perusahaan, harus dikelola dengan baik dan selalu ditingkatkan agar terjalin hubungan yang berkelanjutan dan supplier ikut bertanggungiawab terhadap kualitas produk serta agar distribusi produk dari hulu ke hilir tepat pada waktunya sampai ke pengguna akhir.Maka peningkatan hubungan yang baik dalam jangka panjang serta saling adanya kepercayaan antara perusahaan, supplier dan customer sangat diperlukan agar mencapai efisiensi dalam kinerja operasional.

Pada prinsipnya tujuan akhir yang ingin di capai dalam pengelolaan hubungan jangka panjang adalah profitabilitas perusahaaan yang di peroleh melalui hubungan terus menerus serta saling menguntungkan sehingga terciptanya hubungan jangka panjang yang konsisten dan berkesinambungan. Dari uraian di atas dapat ditarik hipotesis yaitu:

Hipotesis 2: Hubungan Jangka Panjang berpengaruh positif terhadap kinerja Operasional

\section{Hubungan Variabel antara Kerja Sama Terhadap Kinerja Operasional}

Menurut (Simatupang \& Sridharan, 2006) kerja sama adalah suatu altematif terbaik dalam mengelola rantai pasokan secara optimal. Hal ini disebabkan diantara organisasi atau perusahaan yang berada dalam jaringan manajemen rantai pasokan pasti membutuhkan kelancaran dan keakuratan sistem informasi, serta kepercayaan antar organisasi atau perusahaan pengadaan barang dan jasa.

Ketika sebuah perusahaan percaya dengan mitra kerjasamanya dan benar-benar memperlakukan mitra tersebut dengan adil, perusahaan tersebut akan memandang lebih hubungan tersebut sebagai asset strategik dan alat strategik yang akan memperkuat kemampuan bersaing perusahaan. Adanya kerjasama dengan suppher yang dapat diandalkan akan menghasilkan pengertian dan pemahaman yang baik akan kebutuhan dan kepertuan masing-masing pihak sehingga dapat meningkatkan penghasilan perusahaan. Hal ini mendukung penelitian yang dilakukan, untuk mendapatkan kinerja yang baik melahi kerjasama, hubungan yang baik antara kedua belah pihak mutlak dipertukan. Dan berdasarkan dari uraian diatas maka dapat dirumuskan suatu hipotesis sebagai berikut:

Hipotesis 3: Keja Sama berpengaruh positif terhadap kineija Operasional

\section{Hubungan Variabel Antara Proses Integrasi tethadap Kinerja Operasional}

Integrasi rantai pasokan menjadi tema utama dalam menciptakan nilai. Peningkatan produktivitas dalam rantai pasokan produk pangan dapat jika anggota rantai pasokan melakukan integrasi di jaringan rantai pasokannya. Integrasi ekstemal memiliki hubungan yang signifikan dengan kinerja operasi dari jaringan manufaktur, sedangkan integrasi internal tidak berhubungan. Dari hasil penelitian tersebut integrasi eksternal memiliki hubungan yang signifikan dengan kineria operasinal. (Aziz \& Dwiyanto, 2017), yang menyatakan pola integrasi suppy chaim perusahaan mencerminkan fokus operasional perusahaan dalam bersaing di dunia bisnis.

Penelitian empiris yang meneliti hubungan antara integrasi rantai pasokan dan kinerja (Simatupang \& Sridharan, 2006) menyimpulkan bahwa integrasi rantai pasokan secara langsung berhubungan dengan kinerja bisnis. Juga kolaborasi intemal secara langsung mempengaruhi kinerja operasional.

Hipotesis 4: Proses Intergasi berpengaruh positif terhadap kinerja Operasional.

\section{Hubungan Variabel Antara Sinkronisas Keputusan tethadap Kinerja Operasional}

Struktur utama dari sinkronisasi keputusan adalah menyediakan panduan/framework bagaimana cara untuk merencanakan dan mengimplementasikan proses-proses yang baik bagi tiap anggota dalam suppy chaim (Simatupang \& Sridharan, 2006). Sinkronisasi keputusan didefinisikan sebagai sikap untuk memfasilitasi koordinasi pada perencanaan dan eksekusi keputusan antara angoota suppyy chain terkait.

Dalam hubungannya dengan sinkronisasi keputusan, penjajaran insentif memberikan insentif untuk memotivasi anggota rantai untuk membuat keputusan yang efektif yang memperkuat tingkat kinerja yang diinginkan. Sinkronisasi keputusan memberikan umpan balik kepada kinerja operasional mengenai bagaimana metrik kinerja memandu anggota rantai untuk membuat keputusan yang efektif. Sinkronisasi keputusan mengacu 
pada pengambilan keputusan bersama dalam konteks perencanaan dan tingkat operasional.

Hipotesis 5: Sinkronisas keputusan berpengaruh positif terhadap kinerja Operasional.

\section{Hubungan Variabel Antara Keselarasan Intensif terhadap Kinerja Operasional}

Dalam mendukung penyelarasan insentif, sinkronisasi keputusan memberikan pembenaran untuk keselarasan insentif untuk merancang skema insentif yang tepat karena anggota rantai yang berbeda bertanggung jawab untuk tingkat pengambilan keputusan yang berbeda. Akhimya, penyelarasan intensif membantu anggota rantai untuk melaksanakan tindakan produktif terkait dengan proses rantai pasokan terpadu seperti pengisian, transportasi, dan layanan pelanggan.

Keselarasan intensif bertujuan untuk menyediakan mekanisme untuk menyetarakan kembali keuntungan dan beban bersama yang terjadi dalam proses perubahan pada suppy.Dalam hubungannya dengan sinkronisasi keputusan, penjajaran insentif memberikan insentif untuk memotivasi anggota rantai untuk membuat keputusan yang efektif yang memperkuat tingkat kinerja operasional yang diinginkan.

Hipotesis 6: Keselarasan Intensif berpengaruh positif terhadap kimeija Operasional.

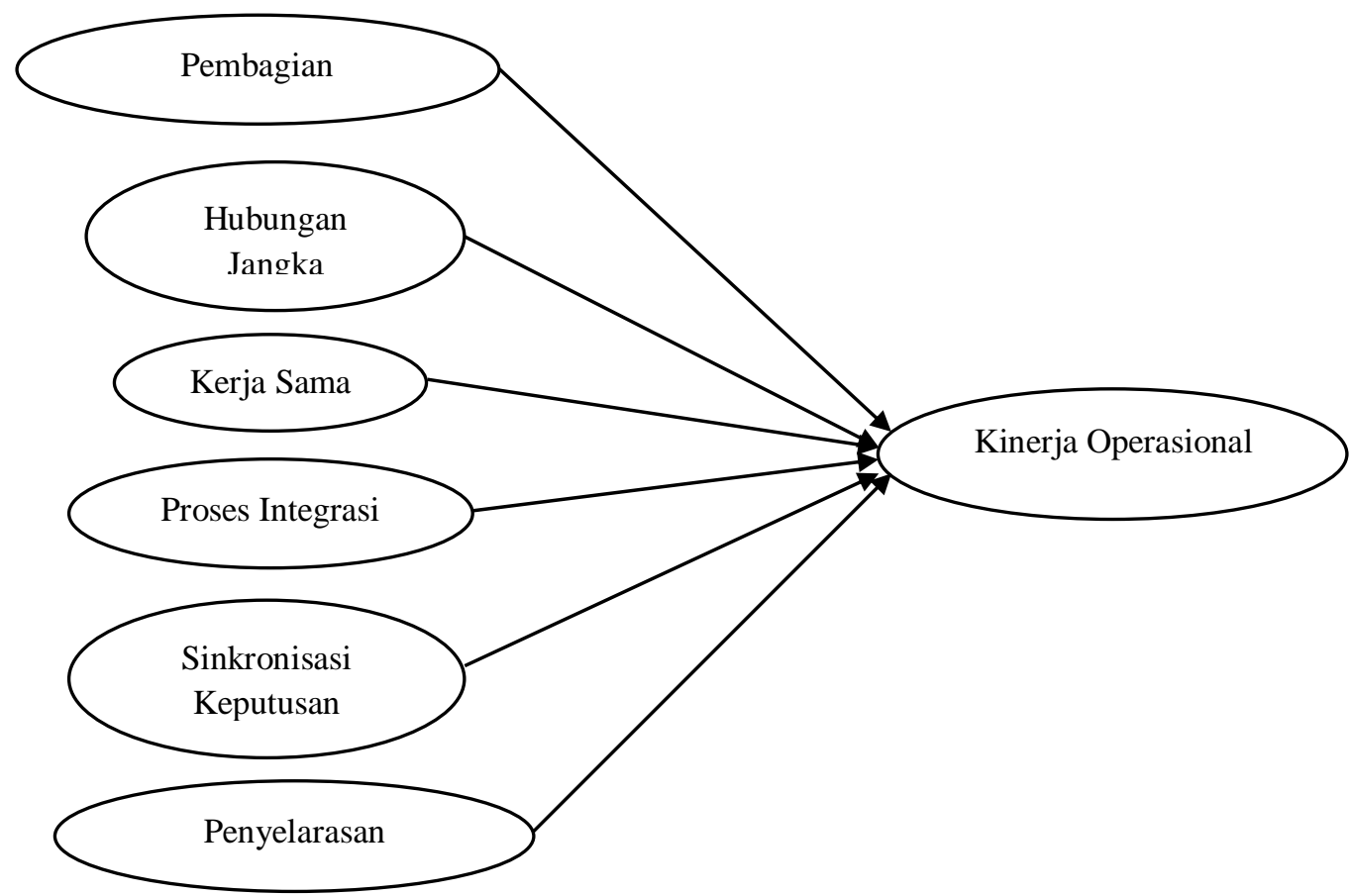

Gambar (1) Alur Fikir

\section{METODOLOGI PENELITIAN}

\section{Populasi}

Menurut (Rahmasari, 2011) populasi merupakan gabungan dari seluruh elemen yang berbentuk peristiwa, hal atau orang yang memiliki karakteristik yang serupa dan menjadi pusat perhatian seorang peneliti karena dipandang sebagai sebuah semesta penelitian. Poplasi dalam penelitian ini adalah Toko Laptop di Kota Ambon.

\section{Sampel}

Sampel merupakan bagian dari jumlah dan karakteristik yang dimiliki oleh populasi. (Rahmasari, 2011) mengatakan bahwa sampel adalah subset dari populasi yang terdiri dami beberapa angggota populasi. Subset ini diambil karena dalam banyak kasus terdapat hal tidak mungkin kita meneliti seluruh anggota populasi, oleh karena itu diperlukannya membentuk sebuah perwakilan populasi yang disebut sampel. Pengambilan jumlah sampel ditentukan berdasarkan Roscoe (1975) dalam (Sekaran, 2006) memberikan acuan dalam pengambilan jumlah sampel, yaitu ukuran sampel lebih dari 20 dan kurang dari 500 adalah tepat untuk kebanyakan penelitian. 


\section{MetodeAnalisis}

Partial L east Squane (PLS) pertama kali dikembangkan oleh Herman O. A. Wold dalam bidang ekonometrik pada tahun 1960-an dalam (Martadisastra, 2017). PLS merupakan model analisis yang poverful karena dapat digunakan pada setiap jenis skala data (nominal, ordinal, interval dan rasio) serta syarat asumsi yang lebih fleksibel. PLS dapat juga dikatakan sebagai metode pendekatan PLS untukpemodelan persamaan struktural. Dalam komunitas PLS, istilah "Path Modeling" lebih disukai daripada Structural Equation Modeling. Meskipun demikian, kedua istilah tersebut dapat ditemukan dalam leteratur PLS.

PLS tidak mengasumsikan data harus mengikuti suatu distribusi tertentu, misal berdistribusi normal. Pendekatan PLS mermpakeandistribution free serta ukuran sampel yang fleksibel. PLS dapat juga digunakan ketika landasan teori model adalah tentatif atau pengukuran setiap konstruk laten masih baru (Yamin dan Kumiawan, 2009). PLS berbasis varian yang didesain dengan tujuan prediksi. Hal ini menjadi konsep awal yang harus menjadi landasan bagi para peneliti. Fokus untama dari PLS adalah memaksimalkan varian konstruk endogen yang mampu dijelaskan oleh konstruk eksogen atau mengidentifikasi konstruk yang mampu memaksimalkan kekuatan prediksi model. (Waters, 2009) menyebutkan PLS dapat juga digunakan untuk tujuan konfumasi (seperti pengujian hipotesis) dan tujuan eksplorasi Tujuan utamanya adalah untuk menjelaskan hubungan antar konstruk dan menekankan pengertian tentang nilai hubungan tersebut.

\section{HASIL DAN PEMBAHASAN}

\section{Hasil Uji Kualitas Data}

Uji kualitas data meliputi realibilitas dan uii validitas. Uji reliabitas dilakukan dengan melihat nilai composite reliability yang dihasilkan dengan perhitungan PLS untuk masingmasing konstruk. Nilai suatu konstruk dikatakan reliabel jika memberikan nilai composite reliability $>0,70$ (Werts et al. 1974 dalam Imam, 2008).

Tabel (1) Hasil Uji Reliabilitas

\begin{tabular}{lcc}
\hline \multicolumn{1}{c}{ Latent variable } & $\begin{array}{c}\text { Cronbach's } \\
\text { alpha }\end{array}$ & $\begin{array}{c}\text { Composite } \\
\text { Reliability }\end{array}$ \\
\hline Pembagian Informasi & 0.942 & 0.963 \\
Hubungan Jangka Panjang & 0.827 & 0.897 \\
Kerjasama & 0.894 & 0.935 \\
Proses Integrasi & 0.875 & 0.923 \\
Sinkronisasi Keputusan & 0.823 & 0.896 \\
Penyelarasan Insentif & 0.814 & 0.890 \\
Kinerja Operasional & 0.898 & 0.936 \\
\hline
\end{tabular}

Sumber: Data primer diolah, 2020.

Konstruk pembagian informasi mempunyai nilai composite rehiability $(0,963)$, nilai tersebut di atas $(0,70)$ sebagai nilai cutoff, maka semua pemyataan tentang pembagian informasi adalah reliabel. Konstruk hubungan jangka panjang mempunyai nilai composite reliability sebesar $(0,897)$ di atas nilai cutoff) maka semua pertanyaan tentang hubungan jangka panjang adalah reliabel. Konstruk kerjasama mempunyai nilai compositte reliability sebesar $(0,935)$ (di atas nilai cutoff) maka semua pertanyaan tentang kerjasama adalah reliabel. Konstruk kerjasama mempunyai nilai composite reliability sebesar $(0,935)$ (di atas nilai cutoff) maka semua pertanyaan tentang kerjasama adalah reliabel. Konstruk proses integrasi mempunyai nilai composite rehiability sebesar $(0,923)$ (di atas nilai cutoff) maka semua pertanyaan tentang proses integrasi adalah reliabel. Konstruk sinkronisasi keputusan mempunyai nilai ompossite reliability sebesar $(0,890$ ) (di atas nilai cutoff) maka semua pertanyaan tentang sinkronisasi keputusan adalah reliabel. Konstruk penyelarasan insentif mempunyai nilai composite reliability sebesar $(0,890)$ (di atas nilai cutoff) maka semua pertanyaan tentang penyelarasan insentif adalah reliabel. Konstruk kinerja operasional mempunyai nilai composite reliability sebesar $(0,890)$ (di atas nilai cutoff) maka semua pertanyaan tentang kinerja operasional adalah reliabel.

Selanjutnya, uij validitas dilakukan dengan menggunakan evaluasi model pengukuran (outer) yaitu dengan menggunakan comergent validity. Comernent validity dari model pengukuran dengan indikator refleksif dapat dilihat dari korelasi antara masing-masing skor indikator dengan skor konstruknya (Ghozali, 2006). Ukuran refleksif individual dikatakan tingoi jika berkorelasi lebih dari $(0,70)$ dengan konstruk yangingin diukur. 
Tabel (2) Hasil Comergent V alidity

\begin{tabular}{lrrrrrrr}
\hline & $\begin{array}{c}\text { Pembagian } \\
\text { Informasi }\end{array}$ & $\begin{array}{c}\text { Hubungan } \\
\text { Jangka } \\
\text { Panjang }\end{array}$ & \multicolumn{1}{c}{ Kerjasama } & $\begin{array}{c}\text { Proses } \\
\text { Integrasi }\end{array}$ & $\begin{array}{c}\text { Sinkronisasi } \\
\text { Keputusan }\end{array}$ & $\begin{array}{c}\text { Penyelarasan } \\
\text { Insentif }\end{array}$ & $\begin{array}{c}\text { Kinerja } \\
\text { Operasional }\end{array}$ \\
\hline PInfo1 & $\mathbf{0 . 9 5 3}$ & 0.663 & 0.649 & 0.745 & 0.551 & 0.591 & 0.790 \\
PInfo2 & $\mathbf{0 . 9 5 3}$ & 0.800 & 0.692 & 0.614 & 0.594 & 0.678 & 0.790 \\
PInfo3 & $\mathbf{0 . 9 3 4}$ & 0.625 & 0.768 & 0.613 & 0.588 & 0.618 & 0.793 \\
HJP1 & 0.692 & $\mathbf{0 . 8 6 0}$ & 0.649 & 0.484 & 0.543 & 0.552 & 0.704 \\
HJP2 & 0.628 & $\mathbf{0 . 9 0 5}$ & 0.663 & 0.508 & 0.655 & 0.861 & 0.683 \\
HJP3 & 0.576 & $\mathbf{0 . 8 1 9}$ & 0.506 & 0.528 & 0.377 & 0.833 & 0.582 \\
KS1 & 0.741 & 0.670 & $\mathbf{0 . 9 1 4}$ & 0.662 & 0.732 & 0.610 & 0.875 \\
KS2 & 0.669 & 0.684 & $\mathbf{0 . 8 5 5}$ & 0.724 & 0.759 & 0.587 & 0.854 \\
KS3 & 0.610 & 0.573 & $\mathbf{0 . 9 5 5}$ & 0.662 & 0.784 & 0.563 & 0.833 \\
PInteg1 & 0.543 & 0.445 & 0.563 & $\mathbf{0 . 8 7 3}$ & 0.494 & 0.372 & 0.688 \\
PInteg2 & 0.590 & 0.485 & 0.658 & $\mathbf{0 . 9 0 9}$ & 0.556 & 0.442 & 0.789 \\
PInteg3 & 0.713 & 0.622 & 0.775 & $\mathbf{0 . 9 0 0}$ & 0.628 & 0.643 & 0.854 \\
SK1 & 0.466 & 0.479 & 0.745 & 0.534 & $\mathbf{0 . 9 0 9}$ & 0.460 & 0.663 \\
SK2 & 0.541 & 0.594 & 0.624 & 0.469 & $\mathbf{0 . 7 8 3}$ & 0.439 & 0.650 \\
SK3 & 0.565 & 0.524 & 0.778 & 0.614 & $\mathbf{0 . 8 8 6}$ & 0.465 & 0.747 \\
PIns1 & 0.667 & 0.832 & 0.583 & 0.435 & 0.577 & $\mathbf{0 . 8 7 6}$ & 0.608 \\
PIns2 & 0.582 & 0.707 & 0.418 & 0.443 & 0.287 & $\mathbf{0 . 8 2 3}$ & 0.496 \\
PIns3 & 0.460 & 0.662 & 0.631 & 0.534 & 0.462 & $\mathbf{0 . 8 6 0}$ & 0.619 \\
KO1 & 0.795 & 0.671 & 0.816 & 0.933 & 0.718 & 0.596 & $\mathbf{0 . 9 3 7}$ \\
KO2 & 0.750 & 0.750 & 0.846 & 0.792 & 0.740 & 0.648 & $\mathbf{0 . 9 2 1}$ \\
KO3 & 0.741 & 0.670 & 0.914 & 0.662 & 0.732 & 0.610 & $\mathbf{0 . 8 7 5}$ \\
\hline
\end{tabular}

Sumber:Data primer diolah, 2020.

Dari tabel diatas, terlihat bahwa semua indikator yang digunakan untuk mengukur semua konstruk dalam penelitian ini mempunyai kisaran korelasi lebih besar dari angka yang disarankan $(0,500)$, hal ini menunjukkan bahwa pemyataan tentang semua konstruk dalam penelitian dapat dikatakan valid.

Pemeriksaan selanjutnya dari evaluasi discrimanant validity adalah membadingkan nilai AVE dari setiap konstruk dengan kuadrat korelasi antar konstruk. 
Tabel(3) Hasil Discrmanant V alidity

\begin{tabular}{|c|c|c|c|c|c|c|c|c|}
\hline & $\begin{array}{c}\text { Pembagian } \\
\text { Informasi }\end{array}$ & $\begin{array}{c}\text { Hubungan } \\
\text { Jangka } \\
\text { Panjang } \\
\end{array}$ & Kerjasama & $\begin{array}{c}\text { Proses } \\
\text { Integrasi }\end{array}$ & $\begin{array}{l}\text { Sinkronisasi } \\
\text { Keputusan }\end{array}$ & $\begin{array}{l}\text { Penyelarasan } \\
\text { Insentif }\end{array}$ & $\begin{array}{c}\text { Kineria } \\
\text { Operasional }\end{array}$ & $\begin{array}{c}\text { Mean } \\
\text { Communalities } \\
\text { (AVE) }\end{array}$ \\
\hline $\begin{array}{l}\text { Pembagian } \\
\text { Informasi } \\
\text { Hubungan Jangka }\end{array}$ & 1 & 0.541 & 0.552 & 0.482 & 0.373 & 0.442 & 0.699 & 0.896 \\
\hline Panjang & 0.541 & 1 & 0.502 & 0.342 & 0.381 & 0.438 & 0.585 & 0.743 \\
\hline Kerjasama & 0.552 & 0.502 & 1 & 0.566 & 0.697 & 0.418 & 0.486 & 0.826 \\
\hline $\begin{array}{l}\text { Proses Integrasi } \\
\text { Sinkronisasi }\end{array}$ & 0.482 & 0.342 & 0.566 & 1 & 0.397 & 0.306 & 0.766 & 0.799 \\
\hline $\begin{array}{l}\text { Keputusan } \\
\text { Penyelarasan }\end{array}$ & 0.373 & 0.381 & 0.697 & 0397 & 1 & 0.280 & 0.641 & 0.741 \\
\hline $\begin{array}{l}\text { Insentif } \\
\text { Kinerja }\end{array}$ & 0.442 & 0.438 & 0.418 & 0.306 & 0.280 & 1 & 0.460 & 0.728 \\
\hline $\begin{array}{l}\text { Operasional } \\
\text { Mean }\end{array}$ & 0.699 & 0.585 & 0.486 & 0.766 & 0.641 & 0.460 & 1 & 0.831 \\
\hline $\begin{array}{l}\text { Communalities } \\
\text { (AVE) }\end{array}$ & 0.896 & 0.743 & 0.826 & 0.799 & 0.741 & 0.728 & 0.831 & 0 \\
\hline
\end{tabular}

Sumber: Data primer diolah, 2020. 
Nilai AVE untuk konstruk pembagian informasi adalah 0,896 sedangkan kuadrat korelasi konstruk pembagian informasi dengan konstruk lainnya (baris pertama dalam tabel) lebih kecil dari nilai AVE konstruk pembagian informasi. Nilai AVE untuk konstruk hubungan jangka panjang adalah 0,743 sedangkan kuadrat korelasi konstruk hubungan jangka panjang dengan konstruk lainnya (baris pertama dalam tabel) lebih kecil dari nilai AVE konstruk hubungan jangka panjang. Nilai AVE untuk konstruk kerjasama adalah 0,826 sedangkan kuadrat korelasi konstruk kerjasama dengan konstruk hainnya (baris pertama dalam tabel) lebih kecil dari nilai AVE konstruk kerjasama. Nilai AVE untuk konstruk proses integrasi adalah 0,799 sedangkan kuadrat korelasi konstruk proses integrasi dengan konstruk lainnya (baris pertama dalam tabel) lebih kecil dari nilai AVE konstruk proses integrasi. Nilai AVE untuk konstruk sinkronisasi keputusan adalah 0,741 sedangkan kuadrat korelasi konstruk pembagian informasi dengan konstruk lainnya (baris pertama dalam tabel) lebih kecil dari nilai AVE konstruk pembagian informasi. Nilai AVE untuk konstruk penyelarasan insentif adalah 0,728 sedangkan kuadrat korelasi konstruk penyelarasan insentif dengan konstruk hinnya (baris pertama dalam tabel) lebih kecil dari nilai AVE konstruk penyelarasan insentif. Serta nilai AVE untuk konstruk kinerja operasional adalah 0,896 sedangkan kuadrat korelasi konstruk kinerja operasional dengan konstruk lainnya (baris pertama dalam tabel) lebih kecil dari nilai AVE konstruk kinerja operasional. Hasil ini menunjukkan bahwa konstruk-konstruk dalam penelitian ini memiliki discrimmant validity yang baik.

Penilaian model dengan PLS dimulai dengan melihat R-square untuk setiap konstruk laten dependen. Perubahan nilai R-square dapat digunakan untuk menilai pengaruh konstruk laten independen tertentu terhadap konstruk laten dependen apakah menpunyai pengaruh yang substantive. Tabel berikut ini merupakan hasil estimasi R-square dengan menggunakan XLSTAT PLS $P M$.

\begin{tabular}{|c|c|c|c|}
\hline $\mathbf{R}^{2}$ & $\mathbf{F}$ & $\operatorname{Pr}>F$ & Critical ratio (CR) \\
\hline 0.973 & 174.949 & 0.000 & 118.486 \\
\hline
\end{tabular}

Sumber:Data primer diolah, 2020.

Tabel di atas menunjukkan nilai $R^{2}$ konstruk kinerja operasional adalah sebesar 0,973 . Semakin tinggi nilai $R^{2}$, maka semakin besar konstruk eksogen tersebut dapat menjelaskan konstruk endogen, sehingga semakin baik persamaan struktural. Nilai $R^{2}$ konstruk kinerja organisasi sebesar 0,957 yang berarti $95,7 \%$ variance kinerja operasional dijelaskan oleh konstruk pembagian informasi, hubungan jangka panjang, kerjasama, proses integrasi, sinkronisasi keputusan, dan penyelarasan insentif sisanya sebesar 2,7\% dijelaskan oleh konstruk lain di luar penelitian ini.

Tabel (5) Hasil Immer Weights (Kinerja Operasional)

\begin{tabular}{ccccc}
\hline Latent variable & Value & $\mathbf{t}$ & $\operatorname{Pr}>|\mathbf{t}|$ & Hipotesis \\
\hline Pembagian Informasi & 0.168 & 3.167 & 0.004 & Diterima \\
\hline Sumber:Data primer diolah, 2020. & & &
\end{tabular}

\section{Hipotesis 2}

Hipotesis kedua $\left(\mathrm{H}_{2}\right)$ menyatakan bahwa hubungan jangka panjang berpengaruh positif terhadap kinerja operasional. Tabel 7 di dibawah ini menunjukkan bahwa

\section{Hipotesis 1}

Hipotesis pertama $\left(\mathrm{H}_{1}\right)$ menyatakan bahwa pembagian informasi berpenganuh positif terhadap kinerja operasional. Tabel 6 di dibawah ini menunjukkan bahwa pembagian informasi berpenganuh positif terhadap kinerja operasional. Pengaruh konstruk pembagian informasi positif $(0,168)$ dan signifikan pada $0,004(3,167>2,045)$. Maka hipotesis 1 diterima. hubungan jangka panjang berpengaruh positif terhadap kinerja operasional. Pengaruh konstruk hubungan jangka panjang positif $(0,149)$ dan signifikan pada 0,037 (2,181 > 2045). Maka hipotesis 2 diterima. 
Tabel (6) Hasil Immer Weights (Kinerja Operasional)

\begin{tabular}{|c|c|c|c|c|}
\hline Latent variable & Value & t & $\operatorname{Pr}>|t|$ & Hipotesis \\
\hline $\begin{array}{l}\text { Hubungan Jangka } \\
\text { Panjang }\end{array}$ & 0.149 & 2.181 & 0.037 & Diterima \\
\hline
\end{tabular}

Sumber:Data primer diolah, 2020.

\section{Hipotesis 3}

Hipotesis ketiga $\left(\mathrm{H}_{3}\right)$ menyatakan bahwa kerjasama berpengaruh positif terhadap kinerja operasional. Tabel 8 di dibawah ini menunjukkan bahwa kerjasama berpenganuh positif terhadap kinerja operasional. Penganuh konstruk kerjasama positif $(0,482)$ dan signifikan pada 0,000 (6,720 > 2,045). Maka hipotesis 3 diterima.

Tabel (7) Hasil Inner Wiights (Kinerja Operasional)

\begin{tabular}{ccccc} 
Latent variable & Value & $\mathbf{t}$ & $\operatorname{Pr}>|\mathbf{t}|$ & Hipotesis \\
\hline Kerjasama & 0.482 & 6.720 & 0.000 & Diterima
\end{tabular}

Sumber:Data primer diolah, 2020.

\section{Hipotesis 4}

Hipotesis empat $\left(\mathrm{H}_{4}\right)$ menyatakan bahwa proses integrasi berpengaruh positif terhadap kinerja operasional. Tabel 9 di dibawah ini menunjukkan bahwa proses integrasi berpengaruh positif terhadap kinerja operasional. Pengaruh konstruk proses integrasi positif $(0,168)$ dan signifikan pada 0,004 (3,167 > 2,045). Maka hipotesis 4 diterima.

Tabel (8) Hasil Immer Weights (Kinerja Operasional)

\begin{tabular}{ccccc}
\hline Latent variable & Value & $\mathbf{t}$ & $\mathbf{P r}>|\mathbf{t}|$ & Hipotesis \\
\hline Proses Integrasi & 0.326 & 6.688 & 0.000 & Diterima \\
\hline
\end{tabular}

Sumber:Data primer diolah, 2020.

\section{Hipotesis 5}

Hipotesis kelima $\left(\mathrm{H}_{5}\right)$ menyatakan bahwa sinkronisasi keputusan berpengaruh positif terhadap kinerja operasional. Tabel 10 di dibawah ini menunjukkan bahwa sinkronisasi keputusan tidak berpengaruh positif terhadap kinerja operasional. Pengaruh konstruk sinkronisasi keputusan positif $(0,037)$ tetapi tidak signifikan pada $0,518(0,654<2,045)$. Maka hipotesis 5 ditolak.

Tabel (9) Hasil Inner Weights (Kinerja Operasional)

\begin{tabular}{lcccc}
\multicolumn{1}{c}{ Latent variable } & Value & $\mathbf{t}$ & $\operatorname{Pr}>|\mathbf{t}|$ & Hipotesis \\
\hline $\begin{array}{l}\text { Sinkronisasi } \\
\text { Keputusan }\end{array}$ & 0.037 & 0.654 & 0.518 & Ditolak \\
Sumber:Dataprimer diolah, 2020. & & &
\end{tabular}

\section{Hipotesis 6}

Hipotesis keenam $\left(\mathrm{H}_{6}\right)$ menyatakan bahwa penyelarasan insentif berpengaruh positif terhadap kinerja operasional. Tabel 11 di dibawah ini menunjukkan bahwa penyelarasan insentif tidak berpengaruh positif terhadap kinerja operasional. Pengaruh konstruk penyelarasan insentif negatif $(-0,73)$ dan tidak signifikan pada 0,236 ($1,209<2,045)$. Maka hipotesis 6 ditolak.

Tabel (10) Hasil Imer Weights (Kinerja Operasional)

\begin{tabular}{ccccc}
\hline Latent variable & Value & $\mathbf{t}$ & $\operatorname{Pr}>|\mathbf{t}|$ & Hipotesis \\
\hline Penyelarasan Insentif & -0.073 & -1.209 & 0.236 & Ditolak \\
\hline Sumber:Data primer diolah, 2020. & & &
\end{tabular}




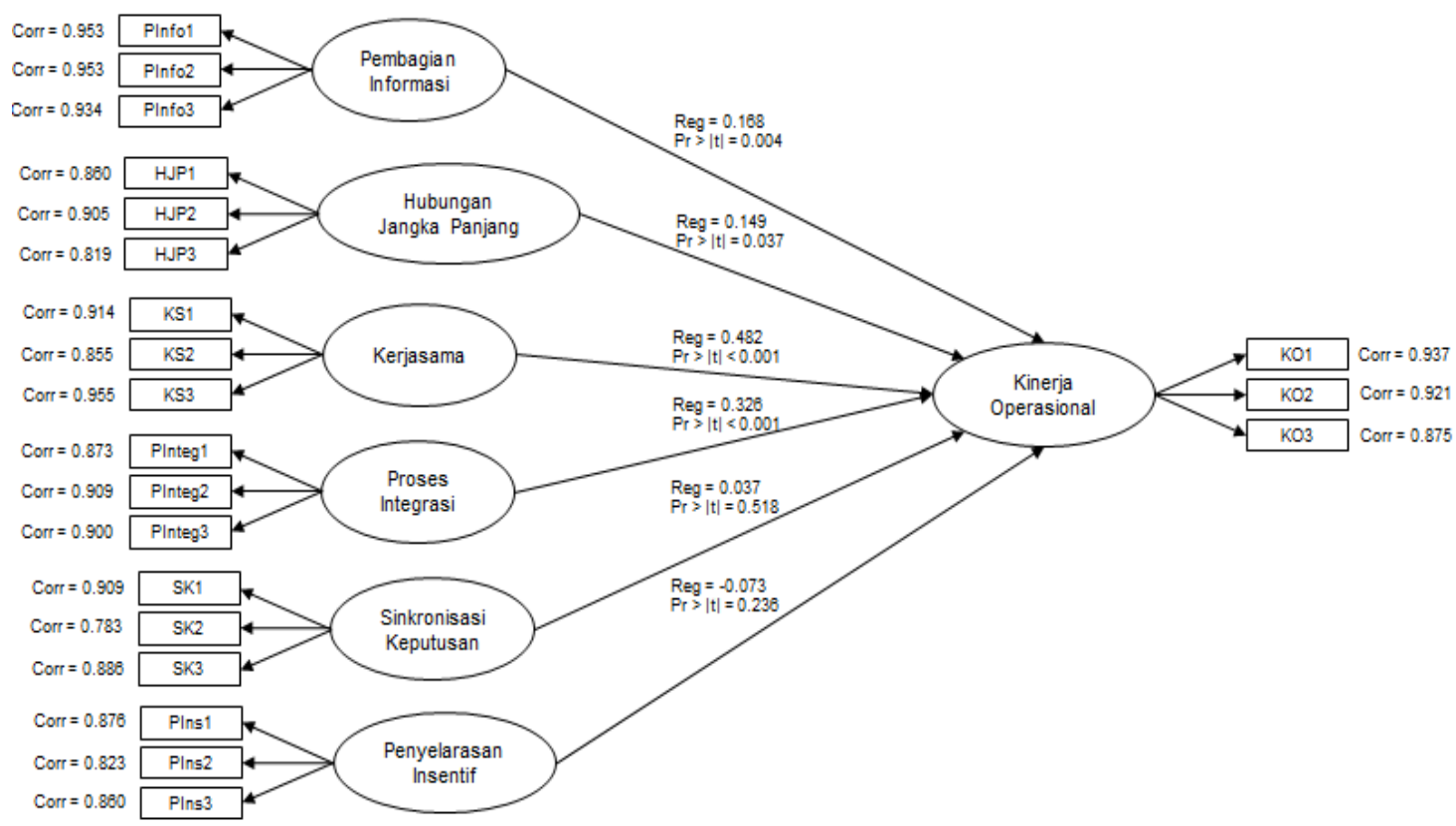

Gambar(2) Full Model

\section{KESIMPULAN}

Penelitian ini berisikan suatu model yang menguii pengaruh dimensi dari supply chain managament terhadap kinerja operasional. Hasil pengujian SEM (Strutural Equation Modeling) dengan menggunakan Partial Least Square, dapat disimpulkan bahwa:

1) Pembagian informasi berpengaruh positif terhadap kinerja operasional. Pengaruh konstruk pembagian informasi positif $(0,168)$ dan signifikan pada $0,004(3,167>2,045)$.

2) Hubungan jangka panjang berpengaruh positif terhadap kinerja operasional. Pengaruh konstruk hubungan jangka panjang positif $(0,149)$ dan signifikan pada 0,037 (2,181 > 2,045).

3) Kerjasama berpengaruh positif terhadap kinerja operasional. Pengaruh konstruk kerjasama positif $(0,482)$ dan signifikan pada $0,000(6,720>2,045)$.

4) Proses integrasi berpengaruh positif terhadap kinerja operasional. Pengaruh konstruk proses integrasi positif $(0,168)$ dan signifikan pada 0,004 (3,167>2,045).

5) Sinkronisasi keputusan tidak berpengaruh positif terhadap kinerja operasional. Pengaruh konstruk sinkronisasi keputusan positif $(0,037)$ tetapi tidak signifikan pada $0,518(0,654<2,045)$.
0) Penyelarasan insentif tidak berpengaruh positif terhadap kinerja operasional. Pengaruh konstruk penyelarasan insentif negatif $(-0,73)$ dan tidak signiffkan pada 0,236 (-1,209<2,045).

\section{DAFTAR REFERENSI}

Anggini, N. (2007). Pengaruh Supply Chain Management Dan Kermggulan Bersaing Terbadap Kineja Perusahaan. 67(0), 14-21.

Ariani, D, Dwiyanto, B. M., \& Manajemen, J. (2013). Analisis Pengaruh Supply Chain Management Terhadap Kinerja Perusahaan (Studi Pada Industri Kecil Dan Menengah Makanan Olahan Khas Padang Sumatera Barat). Junal Studi Manajemen \& Organisasi, 10(2), 132-141.

Aziz, R. T., \& Dwiyanto, B. M. (2017). Analisis Pengaruh Longterm Relation, Information Sharing, Cooperation, Integration Process Terhadap Kinerja Supphy Chain Management (Studi Pada Ukm Kabupaten Gresile). 6, $1-13$.

Barata, C. (2010). Pengarub Rantai Pasokean Kolaboratif Terhadap Kineya Operasional Perusahaan Di Yogyakeanta.

Fitrianto, A. Y., \& Sudaryanto, B. (2010). 'Pengaruh Supply Chain Management Terhadap Kinerja Operasional Outlet ( Studi Pada Counter 
Handphone Yang Terdaftar Di Pt . Multikom Indonesia Cabang Semarang). Diponegoro Joumal of Management,5,1-11.

Hakim, M. F. Al. (2018). Analisis Pengarub Suppy Chain Management Terbadap Kinerja Perusahaan Studi Kasus Pada Industri Roti Dan Kue Di Sumakanta. 4. https://doi.org/10.1590/s180998232013000400007

Huda, M., Aminuddin, A., \& Wusko, U. (2018). Pengaruh Information Sharing, Longterm Relationship, Cooperation, Integration Dalam Suppy Chain Management Terbadap Kineija Perusabaan (Sumri Pada Ikm Pengolaban Makaman Di Kabupaten Pasumuan). 10, 147-162.

J. Rachbini, W. (2019). Supply Chain Management dan kinerja perusahaan. Joumal of Busimess \& Banking, $7(1)$, 23-30. https://doi.org/10.14414/jbb.v711.1463

Latuconsina, Z. (2015). Pengarub Dimensi Kolaborasi Suppy Chain Terbadap Kepenayaan Antar-Organisasi Senta Dampakma Terbadap Kinerja Operasi. IX(2).

Martadisastra, D. S. (2017). Kinerja Pemasok Dalam Rantai Pasokean Makeanan Kemasan: Suatu Käjan Kasus Di Indonesia. 12(1).

Rahmasari, L. (2011). Pengaruh Supply Chaim Management Terhadap Kinerja perusahaan dan Kermgerulan Bersaing (Studi Kasus pada Industri Kreatif di Provinsi Jawsa Tengab). 89-103.

Rani, A. E. (2017). Analisis Pengamub Atribut Kemitraan Terbadap Kolaborasi Rantai Pasok Dan Kineija Operasional Pada IndustriFoodsenvic Di Sumabaya.

Rani, A. E., Baihaqi, I., \& Bramanti, G. W. (2017). Analisis Pengaruh Atribut Kemitraan Terhadap Kolaborasi dan Kinerja Pada Industri Foodservice Di Surabaya. Jumal Sains Dan Semi ITS, 6(2). https://doiorg/10.12962/j23373520.v6i2.25721

Sekaran, U. (2006). Metode Penelition Bisnis. Jakarta: Salemba Empat.

Simatupang, T. M., \& Sridharan, R. (2006). Benchmarking supply chain collaboration. Benchmanking: An International Jounal, 11(5), 484 503.

https://doi.org/10.1108/14635770410557717

Simatupang, T. M., \& Sridharan, R. (2008). Design for supply chain collaboration. Business Process Management Joumal, 14(3), 401-418. https://doi.org/10.1108/14637150810876698
Suharto, R, \& Devie. (2013). Analisa Pengaruh Supply Chain Management Terhadap Keunggulan Bersaing dan Kinerja Perusahaan. Busimess Acounting Revien, 1(2), 161-171.

Talumewo, P. O. E., Kawet, L, \& Pondaag, J.J. (2014). Analisis Rantai Pasok Ketersediaan Bahan Baku Di Industri Jasa Makanan Cepat Saji Pada KFC Multimart Ranotana. Jumal EMBA, Vol 2(3), h 15841591.

Waters, C. D. J. (2009). Supply chain management. In Supply Chain Management (Issue 2001, pp. 1-12).

Yamin dan Kumiawan. (2009). Structural Equation Modeling: Belajar Lebih Mudab Teknile. Analisis Data Kuesioner Dengan Lisnel-PLS. Jakarta: Salemba Infotek.

Yun, Y, \& Kumiawan, A. (2019). Pengamub Integrasi Rantai Pasokean Terhadap Kermogulan Bersaing Melahi Kineija Rantai Pasokean pada Peternak. Sapi Perah. 10(1), 2942. 
Halaman ini sengaja dikessongkean 